バンガロー（平屋）を購入しました. 間取りは日本流に 言うと 1 階が 2LDK で, 日の入る半地下にも部屋が三 つあります. また勝手口からべースメントにアクセスで きるので，こういうタイプの家では，ベースメントを他 人に間貸ししている人もいます. 小さめの物件にしたの で，当初のコンドを買う予算から大幅に変わることなく 家を購入することができ大満足です (写真 5).

\section{VI/ 観光ビザでもカナダに家を}

知り合いの人で日本の会社を定年退職後, 観光ビザ の滞在でカナダに家を購入し, 日本とカナダに半々で住 まれている方がいらっしゃいます，もちろんカナダに 不動産があるのでカナダの固定資産税も払っておられ ます．以前はカナダに来ないときに空いている部屋を 賃貸に出していたそうですが, 最近その家を売り払いダ ウンタウンにコンドを購入したそうです。ちょっと高 級なコンドでは警備を兼ねたフロント業務をする人がい て，ちょっとしたホテルのような感じです．中古物件は MLS (mls.ca) という不動産検索サイトがあり, プライ ベート販売以外のほとんどの物件をインターネットでも 見ることができます．皆さんも MLS でお気に入りの家 があったら円高のうちにカナダに家を購入してみてはい かがでしょうか?

\section{0 最 後 に}

先に述べたエンジニアライセンスの手続きを進める上 で学生時代の論文を提出する必要がありました．原稿は 持っていましたが，論文誌のフッターが付いたコピーの ほうが信憑度があると考え，大学時代の恩師の高橋応明 先生（現, 千葉大准教授）に久し振りに連絡を取ったと ころ，この記事のお話を頂きました. 日本を離れ，研究 を離れてしまった私にこのような機会を与えて頂いて光 栄に思います.

ここに述べたものは，私のカナダ滞在 4 年からの個人 的な経験と感想によるもので, 前述させて頂いたことが いつも当てはまるわけではないことを御理解頂いた上で, この記事が少しでも皆様の参考になれば幸いです。

\section{高橋美枝}

平 9 武蔵工大卒, 平 11 同大学大学院修士課程了 (現, 東京都 市大). 新東京国際空港公団 (現, 成田国際空港株式会社)を経て, カナダに語学留学後, MMM Group Limited に勤務. 家という 巨大なおもちゃを手に入れてどのように改造しようかと考え中.

\section{合成開ロレーダ搭載 地球診断用小形衛星の 実現への道のり}

千葉大学環境リモートセンシング研究センター ヨサファット・テトォコ・スリ・スマンティヨ Josaphat Tetuko Sri Sumantyo

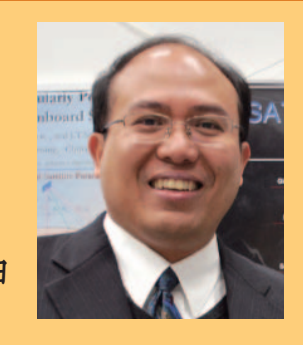

\section{1 日本留学への道のり}

1980 年代に, インドネシアの飛行機産業に偉大な功 績を果たした八ビビ研究・技術大臣（1998～99 年に インドネシア大統領）の影響で, インドネシアの子供た ちが誰でも航空機産業と関連する仕事に憧れた。筆者も 例外ではなく, 航空機のデザイナーになりたいという夢 を持ちながら, 1989 年 7 月にインドネシア中部ジャ ワ県のスラカルタ市 (ソロ市) 第 1 高等学校を卒業して, インドネシア・ガジャマダ大学工学部機械工学科に進学 した. そして, インドネシアの子供たちのもう一つの憧 れは, インドネシア政府派遣留学生として, ドイツと米 国に留学して, 八ビビ研究・技術大臣の研究機関に就職 することである. 当時, インドネシアの社会でも八ビビ 研究・技術大臣の研究機関に入れば, エリートの中のエ リート研究者になれたので, ほとんど皆が同じ夢をもっ ていた. 筆者は, 小学校から高校まで, 飛行機が学校の 上を飛んでいるときに，必ずグランドに出るか，または 空から飛行機が見えなくなるまで見送った. 筆者の父 は, インドネシア国軍空軍の特殊部隊学校の教官で, 家 族と一緒にインドネシア最大教育訓練用空軍基地ソロ駐 屯地内の団地に住んでいた. 学校が休みのときには, よく 父に連れられて空軍基地内の飛行場に行き, 旅客機から 戦闘機まで見せてもらい，たまに戦闘へリにも乗せても らったものだ. 空軍基地内にはインドネシア空軍のレー ダ研究所があり, 空軍の若手スタッフによくRaytheon, Thompson, Plesseyなど様々な種類の軍用レーダを 見せてもらい，筆者は飛行機の他に，レーダにも興味 を持つようになった. まさか, この二つのキーワード である飛行機とレーダが自分の将来に大きく関わるとは 予想もしなかった.

高等学校生だった頃, インドネシア政府が全国の高等 学校生を対象にして, 毎年約 25 名の優秀生を選び, 欧州 と米国の大学に派遣して, 最先端技術を勉強させ, 将来 
インドネシアの科学技術の発展に貢献できる人材の育成 を行っていた. 高校 3 年生から大学 1 年生の間に, ジャ カルタとスラバヤ市で 12 回もの選抜試験が開催され, 全 国から約 5 万人の優秀な候補者が参加した. 筆者がジャ カルタ・セナヤンスタジアム（東京ドームの約 1.5 倍） で開催された第 2 回目の学力試験を受けた際には, 西部 ジャワ島試験域でも約 15,000 人の参加者があった. 試 験中に, スタジアム内の参加者数を見て一時自信を失い かけた. しかし, そのとき, 小学生から高校まで自分がい つも上位の成績の持ち主であったことを思い出し，この 試験を通り抜け, 絶対奨学金を取得し海外で勉強しようと 決心した. 試験の結果は予想どおり合格で, その後次々と 試験を受け，最終的に合格者の中に入ることができた。 合 格発表のときには，合格者はすぐにインドネシア政府技 術応用評価庁 (BPPT), インドネシア科学院 (LIPI), イン ドネシア航空宇宙局 (LAPAN), インドネシア原子力局 (BATAN) など, インドネシアのエリート研究機関に配属 になって, 留学先も決まった. 筆者はずっと航空機デザ イナーになりたいという夢を持っていたので, 留学先は, 第 1 希望を八ビビ研究・技術大臣の若い頃の留学先であ るドイツに，第 2 希望と第 3 希望を米国と日本の航空工 学科にし, また, 配属先は, BPPT, LAPAN, LIPI の順 に志望した. ジャカルタ市内にある BPPT 本部で最終合 格者の発表をした際, 掲示板に筆者の名前, BPPT, 日 本, 電気工学が書かれていた. この発表内容を何回も確認 して,「電気工学」が自分の専門にしたい夢と余りにも離 れてしまったので, 正直がっかりし, 納得できなかった. この発表内容を持って, すぐに両親と相談したが,「自分 の夢をずっと大事にすれば, 違う道 (専門分野) を通って も必ず同じ目的地（夢）に着く」と母親から言われた. 筆 者はこの言葉に半信半疑であったが，この結果を受け入 れた。 翌日からジャカルタ市内の日本語学校に入学し, 早 速今まで夢にも見たことのない平仮名, 片仮名, 漢字, 日 本事情などを 6 か月間で特訓された。

1990 年 3 月末にいよいよ留学のため, 日本に出発し た. 日本に行く前に，多くのニュースと映画を見すぎた せいか, 日本が最先端の科学と技術を持つ国であり, 日本 は「ターミネーター」という 1980 年代の映画に出た都市 と似ているといつも想像していた。 そのため, 飛行機の中 では, 成田国際空港に到着する前から，どきどきしながら 早くこの国を見たいという強い気持ちで一杯だった。 し
かし, 自分が飛行機の左側の席に座ったので, 飛行機が南 房総半島上空に左旋回したときに，一番初めに目にした ものは田んぼだった. 余りに自分の想像と現実がかけ離 れていたので,「なんで, 日本に田んぼがあるの!」と心 の中で叫んだ. 成田国際空港から調布市柴崎町のアパー トに向かう途中でも田んぼをたくさん見て,「やっぱり日 本の環境はインドネシアと余り変わらないんだ!きっと, 自分もこの国の生活にすぐに慣れて, インドネシアと日本 のために, いろいろ貢献しょう」と決心した.

\section{2 日本留学から就職へ}

1990 年 4 月から新宿区にある国際学友会日本語学校 で更に日本語を 1 年間勉強して, 大学しベルの講義が受 けられるように特訓した. 東京では, インドネシア政府奨 学金で比較的充実した生活をし, インドネシアの高等学校 で勉強中の二人の兄弟のために毎月仕送りもでき, 二人共 大学院を修了するまで筆者が支援した. しかし, 自分は言 語があまり得意ではないせいか, なかなか日本語の勉強 が進んでいかなかった. 周りの友達が皆順調に日本語を話 せる様子を見て, 「なぜ自分はうまく日本語を身に付けられ ないのか, と思った. 夏休みの頃焦りが出はじめ, 日本で の勉強が順調に進められるかどうか心の中は不安な気持ち で一杯となり, 日本での勉強を断念しようと思うことが何 回もあった. 都内での生活の中でも, よく会話の中で勘違 いが起きて, 何度も人に怒られたことがあり, これから日 本での生活になじめるかどうか更に不安になった.

1991 年 3 月に様々な試験を受けて, 金沢大学工学部 電気・情報工学科に進学することになったとインドネシ ア政府から報告を受けた、「金沢」と聞いたとき，すぐに 神奈川県の金沢だと思い, 都内と近いので安心していた が，翌週に石川県の金沢市行きの電車の切符をもらった ときに, やっと石川県にある金沢大学だと気付いた. 金 沢に向かう途中, 日本海に沿って走る電車から雪を初めて 見たので, とても感動した. 今までインドネシアで雪を直 接見たことがないので，金沢市内に足を踏み入れたとき に, すぐに雪を握りしめて, 「これは本物の雪だ!」とつ ぶやいた. 1991 年 4 月 1 日, 金沢大学の入学式に出席 し, 学長との面談のため, 学長室にも招かれた. 金沢城内 キャンパスで教養部の講義を受けたときに, 先生方の話を うまく聞き取れないことがしばしばあった. 特に, 歴史 の講義では先生が 6 枚の黒板にたくさん文字を書いたが, 
1 ～2 個の文字しか読めなかった. このような日々を過 ごしながら, 他学生の学習のスピードにどんどん追いつけ なくなり, 不安な日々を過ごした。 また, インドネシア政 府派遣留学生の数名が精神的に落ち込み, 留学を断念して 帰国したと聞いたときには，ますます不安になった。 そん なときの, 一番の楽しみはお母さんと家族との毎月の国際 電話での会話だった. 当時, 小立野キャンパス近くに住ん でいたが，兼六園の近くの石川県厚生年金会館前にあっ た電話が，唯一の国際電話ボックスだった。 ちょうど割 引通話になる夜 11 頃以降に, 実家に毎月 1 回決まった 時間に電話をかけたが, 冬の時期の夜間電話が一番辛かっ た. 毎回お母さんに勉強の進渉状況, 生活の苦労話などを 語り, いつも恳めてもらった. 教養部の生活では, 石川県 と富山県出身の三人の日本人学生（渡辺君, 安田君, 八木 君）と仲良くなり, 入学 2 年目にして, やっと日本語や 生活情報が多く身に付けることができたので, 多少日本 での生活に慣れた気がした. 当時, 留学生をはじめ, 専門 に上がれないで留年した学生が，新聞記事になるぐらい 多く, 自分が小立野キャンパス内にある工学部に上がれ ることができたときには安心した. その後, 教養部が角間 キャンパスに移転したので, 自分たちが金沢城内キャン パスでの最後の学生となった. 教養部のとき, ほぼ 1 年 半の間兼六園に毎日通い, $1 \sim 2$ 分の観光気分を味わっ た. 当時, 学業と日常生活が大变だったが, 良い思い出を たくさん作ることができた.

金沢に着いたとき，自分は必ず 2 年間で日本語をマス ターして, 皆と同じレベルの理解度になろうと決心してい た.おかげで, 電気・情報工学科または専門に上がり, 4 年生のときに長野・八木谷研究室に配属になり, 地下探 査レーダの研究と出会った，学部を卒業する際には，成 績が学科で 10 位以内に入っており, 修士課程に進学し た. 修士課程でも, 同研究室にて, 地下探査レーダにお けるハードウェアの開発と時間領域差分 (FDTD : Finite Difference Time Domain) 法による地中における電波 伝搬のシミュレーションを行った. 当時, レーダに様々な 疑問を持ったまま, 1997 年に修士課程を修了した。同大 学の博士課程の入学試験に合格したが, 奨学金がなかった ので, 残念ながらインドネシアに帰国せざるを得なかった.

1997 年 4 月に, 八ビビ研究・技術大臣が長官だっ た BPPT に配属になった.レーダ開発部門がなかった ので, 学部と修士課程で研究した地下探査レーダの開発
をこの機関で継続しようと科学技術庁に申請して, 研究 費を取得した. その頃, インドネシアの最初の地下探査 レーダを実現し, 様々な新聞にも取り上げられた。 しか し, $1997 \sim 98$ 年に, 韓国に起こった通貨危機後, イン ドネシアも例外なく通貨危機に陥り, 研究費が 6 割も カットされた. 当時, 遣り繰りしながら地下探査レーダ の実現に向けて, バンドン工科大学とインドネシア科学 院の研究員と共同研究を行った. 八ビビ研究・技術大臣 が 1998 年にインドネシアの大統領になった際, イン ドネシアの政治と経済状況が更に深刻化し, 研究環境も 更に悪化していった. インドネシアの政治経済の状況が良 くなるまで, 時間がかかり, 自分の年齢を考えて研究生命 を無駄にしたくないので, 1998 年 12 月に妻が留学した 千葉大学に進学しようと決心した。

1999 年 4 月に, 日本語, レーダ, 電波伝搬解析の知 識を持ち, 千葉大学大学院自然科学研究科・環境リモ一 トセンシング研究センターの建石・竹内研究室の博士後 期課程に進学した. 当センターではレーダを専門とした教 員がいなかったので, リモートセンシング分野と一番近い 合成開口レーダ (SAR : Synthetic Aperture Radar) の 研究を始めた. SAR に関する知識は多少あったが, もっ といろいろ研究に展開させたいと思った. 博士号を取得す るために, 2 編の原著論文が条件であったが, 自分自身が インドネシアで研究できなかった分を千葉大学でより多 く研究したいと決心した. 博士課程期間中に, SAR にお ける様々な電磁波散乱解析手法を提案し, 熱帯森林のバイ オマスと泥炭地の厚みの推定などを行い, International Journal of Remote Sensing はじめ, 日本写真測量学 会誌などに 10 編以上の原著論文を書いた。博士課程は 2002 年に無事に修了して, 英国・レスター大学, イス ラエル・ヘブライ大学, 米国・マサチューセッツ大学な どから, 講師になるオファーを受けた. 自分が既に日本の 環境に慣れて, 友人もたくさんおり, 研究におけるヒュー マンネットワークもできたので, この多数のオファーに 対して, なかなか日本から離れられないと複雑な気持ちで 一杯だった. 特に, 修士課程と博士課程では, ロータリー 国際奖学財団, 岡本奨学財団, サト一国際奨学財団 (現在, 佐藤陽国際奨学財団), 渥美国際奨学財団の奨学金で支援 を受けていた. 来日した際の, 「何か将来この国に貢献し たい」という気持ちを思い出した. また, SAR システム に関して, 日本でもっと様々なものを研究したいという 


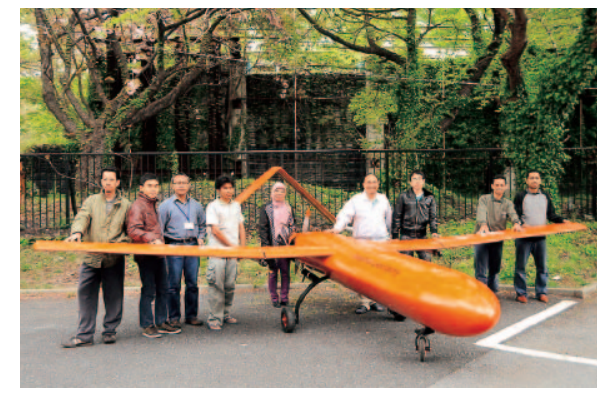

写真 1 学生と一緒に開発した無人航空機

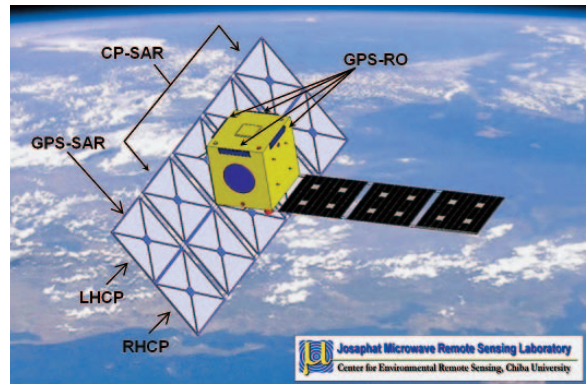

写真 2 円偏波合成開ロレーダ搭載小形衛星

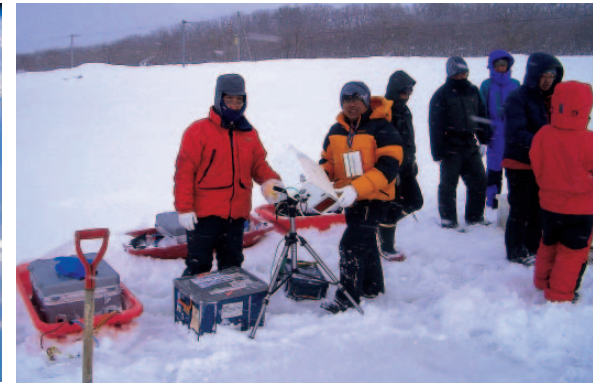

写真 3 北海道サロマ湖に学生と一緒に 雪水によるマイクロ波散乱実験
気持ちもあり，特にアンテナ部分の開発分野で自分をもっ と磨きたいと思ったので，千葉大学電子光情報基盤技術 研究センターと工学部伊藤公—教授の研究室に講師（中核 的研究機関研究員）として在籍し，透明アンテナ，パッチ アレーアンテナなどに関する研究を開始した. 2002 05 年の間に，技術試験衛星VIII形（ETS- VIII）用の地上移 動体衛星通信用の様々な円編波パッチアレーアンテナを 開発し, IEEE TAP, IEE MAP (現在 IET MAP), IJNM などに原著論文が掲載された。この 3 年間の研究成果を 踏まえて, 2005 年 4 月より千葉大学環境リモートセン シング研究センター（CEReS）の助教授 (専任教員) にな り, 合成開口レーダ (SAR) の研究に戻った。

\section{3 研究環境と生活}

現在，筆者は当センターのある一つのプロジェクト研 究リーダとして, マイクロ波でのリモ一トセンシング情報 の統合と活用, 次世代小形衛星センサによる大気情報と植 生情報を含むグロ一バルな環境情報の取得など，先端的リ モートセンシングの創生と新たな環境情報の創出を目指 している. 具体的には, 日本をはじめ, 中国, マレーシア, インドネシア, ネパール, モンゴル, エジプトなど, 様々 な国からの留学生と一緒に独自に Lバンド SAR センサ 搭載の大形無人航空機（写真 1) と小形衛星（写真 2) を 開発し，実証実験も行っている（写真 3). まさに，子供 の頃, 夢に見たものが千葉大学で全てそろえられている.

この研究環境は千葉大学をはじめ, 文部科学省, JAXA, ESA, 情報通信研究機構, インドネシア政府, マレーシア政府，国内の各関連会社（Weathernews な ど）などより支援を頂いた結果であり，マイクロ波リ モートセンシング分野における様々な研究と教育を推進 することができた．当研究室の多くの大学院生も母国に 帰国し, リモートセンシング研究室または研究センター を開所し, 当研究室と当センターのリモートセンシング 観測ネットワークを拡大した. 将来, 当研究室の小形衛
星が打ち上げられれば，これらの海外研究センターに データの受信と解析を協力してもらい, グローバル地球 診断ネットワークをより強化できると期待する. 更に, 国内外の学会 (IEEE, IEICE など), 財団などの仲間の おかげで, 当研究室の活動が様々な場面で支援を頂い たので, 当研究室の活動をより前進でき，マイクロ波リ モートセンシングにおける教育研究活動ができた.

生活面に関して，日本に留学すると決まったときに， 父が日本の「郷に入れば郷に従え」と同様の意味のインド ネシアの言葉を言ってくれたので，日本に来てからいつ もこの言葉を思い出しながら努力して従っている. そのた め, 現在に至るまで日本をはじめ, 世界の様々な文化を身 に付けて生活してきた. 特に, 子供の頃, 日本の京都と同 じ，インドネシアの古都である中部ジャワ県ソロ市内で 育てられて, 日本の文化と似ている習慣が多かったので, 日本に留学し始めたときに, 日本語以外, 日本の習慣にあ まり抵抗を感じなかった. 中部ジャワの風習と習慣が日 本よりもっと複雑で, 何か表現するときに通り回ること が更に多いので, 日本の習慣にすぐになじんだ.もっと深 く研究しかつ現地の社会に貢献できるために, やっぱり 現地の習慣や風習などを理解すべきであると実感した。こ れによって, 国内の研究, 教育, 会社などから一般の方々 まで幅広い方々と交流ができ, 自分の研究に応援を頂き, 日本で有意義な研究環境が実現できた。

日本に来て金沢大学で勉学した際, 富山大学に留学し ていた同国出身の家内と知り合って, 1997 年にインド ネシア・バンドン市内で結婚した。 家内はバンドン工科 大学の准教授で, パブリックアートを專門とした, 彫刻研 究室を経営している. その作品は, 既に日本, 中国, 韓国, インドネシア, オランダなどの博物館, 公園, 銀行, 公共 機関など, 様々なところで永久設置されている. 家内が海 外で活躍している際, 筆者が千葉市内の中学校に通ってい る息子と一緒に暮らし, 仕事と家事を両立しながら生活し てきた. 日本の社会では, 仕事と家事を両立してバランス 
を維持するために，とても大変であるが，息子とたくさん の会話ができたので, 大变貴重な時間を得たと実感してい る. この会話の中の, 子供の発想はアンテナから小形衛星 の研究まで大変役に立ち, 特許まで取得した. また, 国内 外の学会, 講習会, 講演, 講義などのために, いつも息子 を連れて行っている．息子にもたくさんの経験をして，将 来本人の役に立ち, 世界により貢献してほしいと期待して いる. いつか息子と離れるとき後海したくないので, 現在 子供との時間を大切にしている.

日本での経験，知識，構築したネットワークなどを世界 にもっと貢献するために，2001 年に筆者がまだ千葉大 学大学院の博士課程に在籍したときに, 家族と一緒にイン ドネシア・バンドン市内でパンディトパンジ財団 (http:// www.pandhitopanji-f.org)を構築した. パンディトパン ジという名前は息子の名前に由来し，今まで日本で家族と 一緒に生活した意味を表現したものである.この財団はリ モートセンシング研究センター (RSRC), 美術研究セン ター (ARC), 教育研究センター $(E R C)$ より構成されてい る. RSRC では国内外の研究機関と一緒にインドネシアの 環境モニタリングに関する研究をしている. ARC に関して, 世界の美術家と一緒に様々な美術活動を行っている. 最後 の ERC がインドネシアの子供たちに, 小学生から大学院 修士課程までの奨学金を与えている. また, リモートセン シングと美術関連の書籍を出版し，この両分野の発展と推 進に貢献したいと思う. 2011 年にバンドン市内に新築の 研究センターとゲストハウスができ, より財団の活動を世界 に拡大できると期待する. また, この財団が現在に至るま でインドネシア政府をはじめ, インドネシア国内の研究機 関, 教育機関, 会社などに様々な貢献ができた。 これから も若手研究者の人材育成を通して, 日本とインドネシアの 科学技術の架け橋になると期待している.

\section{ヨサファット・テトォコ・スリ・スマンティヨ (正員)}

1970 インドネシア・西部ジャワ生まれ. 1997 金沢大大学院工 学研究科電気 . 情報工学専攻修士了. 2002 千葉大大学院自然 科学研究科人エシステム工学専攻博士了. 博士 (工学). 1990 ～99 インドネシア政府技術応用評価庁 (研究員), 2002 05 千葉大電子光情報基盤技術研究センター（講師·中核的研 究機関研究員), 2005 千葉大環境リモートセンシング研究 センター(准教授·専任教員). 合成開ロレーダ, 小形衛星, 無 人航空機などを開発. 国内外の大学と研究機関の評議員, 客員 教授, Adjunct Professor などを兼務し, IEICE SANE 研専 門委員, IEEE, 日本写真測量学会 (JSPRS), 日本リモートセ ンシング学会 (RSSJ) 各会員.

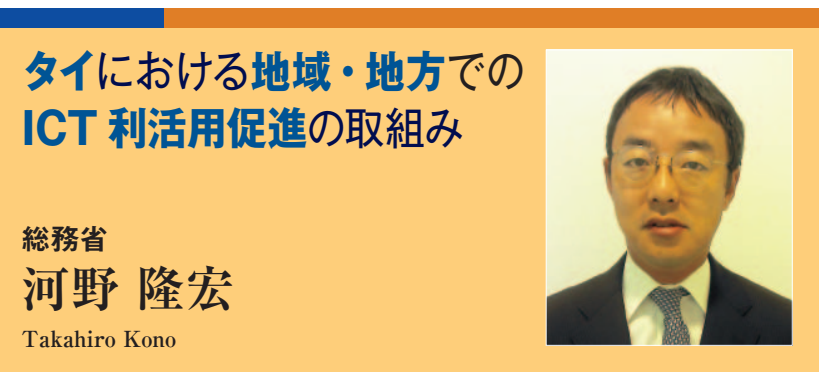

\section{1 はじめに}

筆者は, 2009 年 9 月から 2011 年 9 月の 2 年間, JICA (Japan International Cooperation Agency) 専 門家として, タイの ICT 省にICT 政策に関するアドバイ ザーとして勤務することとなった。 ここでは, タイにおけ るICT 事情について簡単に触れるとともに, 地域・地方 でのインターネット等ブロードバンドの利活用促進を図 るために, ICT 省が管理・運用しているICT コミュニティ テレセンターの活動について, 述べることとしたい.

\section{2 タイにおける ICT 事情（図 1)}

情報通信インフラストラクチャに関して, タイは他の発 展途上国同様, 固定電話インフラが整備される前に, 携 帯電話インフラが急速に整備されている. また, タイは日 本以上に地域格差, 特に首都バンコクとそれ以外の地方 部の格差が激しく, 例えば, 情報通信分野での一例とし て, 固定電話の普及率を比べると, 首都圏は $37 \%$ なの に対し，それ以外の地方部では $6 \%$ に留まっている. こう いったこともあり, タイでは, いわゆる地域におけるディジ タルデバイドの解消が大きな政策課題の一つとなっている. タイ政府では, 2010 年末から様々なICTビジョンが策 定されているが，その中でもブロードバンドの整備目標は, 大きな柱の一つとなっている. すなわち, 2015 年までに 少なくとも人口の $80 \%$ が，また 2020 年までに少なくと

\begin{tabular}{|c|c|c|c|c|c|}
\hline & & Thailand & \multicolumn{2}{|c|}{ Japan } & Note \\
\hline \multirow[t]{2}{*}{ Fixed Telephone } & Subscribers & $7,024,000$ & 51,232 & 000 & \multirow{2}{*}{ As of end of 2007} \\
\hline & Penetration & $11 \%$ & 40 & & \\
\hline \multirow[t]{2}{*}{ MobileTelephone } & Subscribers & $79,066,000$ & 107,33 & 9,000 & \multirow{2}{*}{ As of June 2007} \\
\hline & Penetration & $124 \%$ & 84 & & \\
\hline \multirow[t]{2}{*}{ Internet } & Subscribers & $13,416,000$ & 88,110 &, 000 & \multirow{2}{*}{ As of end of 2007} \\
\hline & Penetration & $21 \%$ & 69 & & \\
\hline \multirow{3}{*}{\multicolumn{3}{|c|}{$\begin{array}{l}\text { (参考) 人 口 } \\
\text { タイ } \\
\text { 日本 }\end{array}$}} & \multicolumn{3}{|c|}{ (参考) 固定電話の普及率 } \\
\hline & & & \multirow{2}{*}{\begin{tabular}{|l|} 
首都圏 \\
37.08 \\
\end{tabular}} & \multirow{2}{*}{$\frac{6.09}{6.2}$} & 全体 \\
\hline & & & & & 10.47 \\
\hline \multicolumn{2}{|c|}{ 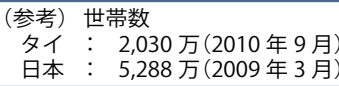 } & & & & \\
\hline
\end{tabular}

図1 日本·タイの電気通信比較 